\title{
BIOSORPTION OF ZINC FROM AQUEOUS SOLUTION USING ALGAE AND PLANT BIOMASS
}

\author{
IVA MELČÁKOVÁ, TOMÁŠ RU゚ŽOVIČ \\ VŠB TU-Ostrava, Institute of Environmental Engineering, Faculty of Mining and \\ Geology, Ostrava, Czech Republic (iva.melcakova@vsb.cz, tomas.ruzovic.st@vsb.cz)
}

\begin{abstract}
In the present study, the sorption capacity of plant biomass has been studied; particularly the ability of biomass algae Chlorella vulgaris, filamentous green algae Spirogyra sp. and roots, stems and leaves of an invasive plant Reynoutria japonica to bind up $\mathrm{Zn}^{2+}$ ions. The results of this biosorption study revealed that the rate and extent of uptake were affected by $\mathrm{pH}$ level, contact time and initial metal concentration. The maximum uptake of metal ions was obtained at $\mathrm{pH}$ 6.0. The equilibrium sorption data for metal system at pH 6 were described by the Langmuir isotherms model. For $\mathrm{Zn}^{2+}$, sorption capacity $\mathrm{q}_{\max }$ of $17 \mathrm{mg} / \mathrm{g}$ was achieved using biomass from leaves. Removal of $\mathrm{Zn}^{2+}$ with $1 \mathrm{~g}$ of biosorbent from leaves was almost $77 \%$ when present in low concentrations, whereas it is lower at higher concentrations.
\end{abstract}

Keywords: Chlorella vulgaris, Spirogyra sp., Reynoutria japonica, biosorption, zinc, isotherm

\section{Introduction}

Metal pollution is one of the most important environmental problem today. Three kinds of metals are of concern, including toxic metals (such as $\mathrm{Hg}, \mathrm{Cr}, \mathrm{Pb}, \mathrm{Zn}, \mathrm{Cu}, \mathrm{Ni}$, $\mathrm{Cd}$, As, $\mathrm{Co}, \mathrm{Sn}$ etc.), precious metals (such as $\mathrm{Pd}, \mathrm{Pt}, \mathrm{Ag}, \mathrm{Au}, \mathrm{Ru}$ etc.) and radionuclides (such as U, Th, Ra, Am, etc.) (WANG and CHEN, 2009). Metals can be distinguished from other toxic pollutants, since are non-biodegradable and can accumulate in the living tissues, thus becoming concentrated throughout the food chain (WILLIAMS et al., 1998).

By far the greatest demand for metal sequestration comes from the need for immobilizing the metals "mobilized" by and partially lost through growing and everintensifying human technological activities. Pollution of the environment by toxic metals arises as a result of many human activities like mining, metallurgy, electroplating, leather tanning, metal finishing, textile industry, and paper industry. Effects of these metals on ecosystems are of large economic and public-health significance (VOLESKY, 2001).

Biosorption and bioaccumulation belong to the group of biological methods suitable for heavy metal removal from wastewater (KADUKOVÁ and VIRČÍKOVÁ, 2005). The biosorption is relatively new technology and could be considered for its economic edge as a possible alternative technique for metal recovery. In recent years, biosorption has been widely studied for the removal of metal ions, especially at the concentrations ranging from 1 to $100 \mathrm{mg} / \mathrm{l}$, due to its lower costs and higher effectiveness than the conventional methods such as chemical precipitation and ion exchange (HAN et al., 2008). Different biomass have been used to adsorb metal ions from the environment. Bacteria, fungi, yeast, algae, and plants have proved to be 
potential metal sorbents (GUPTA et al., 2000; ROMERA et al., 2007). While choosing biomaterial for metal sorption, its origin is a major factor to be taken into account; it can come from a) microorganisms as a by-product of fermentation industry, b) organisms naturally available in large quantities in nature and c) organisms cultivated or propagated for biosorption purposes using inexpensive media (AHLUWALIA and GOYAL, 2007). Understanding the sorption of metal ions from aqueous solution is important for apllication in industrial water treatment.

In this study we wanted to compare biosorption of zinc by laboratorly cultivated species Chlorella vulgaris with ubiquitous and in large quantities in nature found species Spirogyra sp. and Reynoutria japonica. Chlorella vulgaris is fast-growing edible algae, cultivated on large scale, and used as a food or feed supplement (CHOJNACKA, 2007). Several studies (BISHNOI et al., 2007; GUPTA et al., 2006; GUPTA and SHARMA, 2008) has been reported about Spirogyra sp., harvested from natural populations, which have exhibited its excellent ability to remove chromium, copper and lead from aqueous solutions. The cell wall of Spirogyra sp. is very similar to that of terrestrial plants because its main components are cellulose and pectin. Last species - Reynoutria japonica - is an invasive ubiquitous plant investigated currently as a possible energetic plant. It is also known that the species of this genus are able to accumulate heavy metals from soil.

Zinc is the fourth among metals of the world in annual consumption. It is extensively used in the automobile industry, for the production of protective coatings for iron and steel, in cosmetics, powders, ointments, antiseptics, paints, varnishes, rubber and linoleum. Zinc is also needed for manufacturing of parchment papers, glass, automobile tires, television screens, dry cell batteries and electrical equipment. The main sources of $\mathrm{Zn}$ in the environment are zinc fertilizers, sewage sludges and mining and smelting (BRADL et al., 2005). The average human body contains about 2 grams of zinc, which is essential for the normal activity of DNA polymerization and for protein synthesis. Soluble and astringent acid salts, such as $\mathrm{ZnSO}_{4}$ in large doses (about $10 \mathrm{~g}$ ), have caused internal organ damage and death (GUPTA and SHARMA, 2003).

\section{Materials and methods}

The culture of unicellular algae species, Chlorella vulgaris (Fig.1), the culture of filamentous green algae Spirogyra sp. (Fig. 2 and 3) and plant Reynoutria japonica (Fig.4) were used for laboratory experiments.

\subsection{Chlorella vulgaris cultivation}

Chlorella vulgaris in log phase used in the experiments was inoculated in medium Milieu Bristol, modification $3 \mathrm{~N}$, at $\mathrm{pH}$ 7. The medium was sterilized by autoclaving at $121^{\circ} \mathrm{C}$ for 15 minute. Medium was stored at $4^{\circ} \mathrm{C}$ until inoculated. Cultures were grown in liquid media in $2 \mathrm{~L}$ glass Erlenmeyer flasks, aerated with filtered air, and incubated at $25^{\circ} \mathrm{C}$ on a light table. Samples were taken every $24 \mathrm{~h}$ using sterile glass pipettes. In the samples the cell counts were obtained using the Thoma cellula, and the content of 
pigment chlorophyll a was determined by $\mathrm{DU}^{\circledR}-64$ Spectrophotometer (Beckman, memory PAC ${ }^{+M}$.

\subsection{Preparation of biosorbents}

When Chlorella vulgaris cultures reached the stationary phase, they were harvested and used for metal ion biosorption experiments. Chlorella vulgaris was first cooled down in order to ease following centrifugation (10 minutes at $3000 \mathrm{rpm})$, and obtained biomass was extensively washed two times with water $(1 \mathrm{~L}$ of de-ionized water per $1 \mathrm{~g}$ of biomass) to get rid of medium remnants. Then it was dried in the oven (at $60^{\circ} \mathrm{C}$ ) overnight and pulverized in a grinding mortar. Acid pre-treatment was then done by washing the sorbent with $0.2 \mathrm{M}$ solution of $\mathrm{H}_{2} \mathrm{SO}_{4}(1 \mathrm{~L}$ of acid per $1 \mathrm{~g}$ of biomass for 90 minutes), washing twice again by de-ionized water, centrifuged once more and dried 24 hours at constant temperature of $60^{\circ} \mathrm{C}$.

Filamentous green algae Spirogyra sp. was collected from a fresh water pond. The sorbent was then prepared using the same procedure as described above.

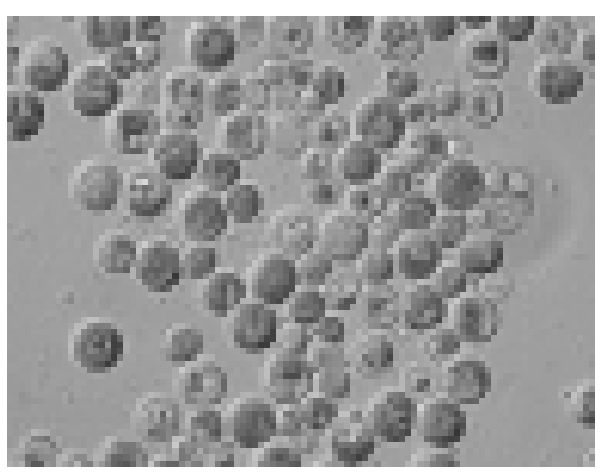

Fig. 1. Chlorella vulgaris

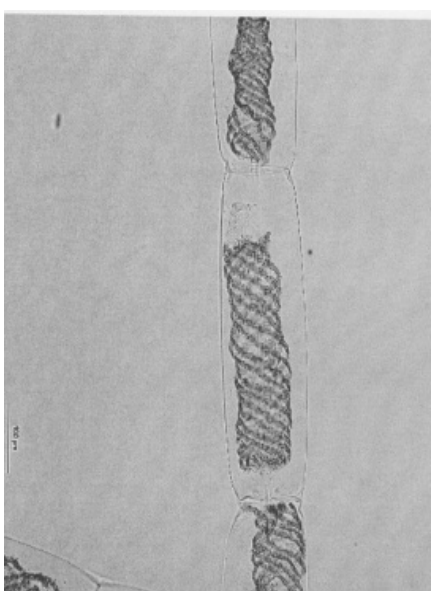

Fig. 3. Spirogyra sp.

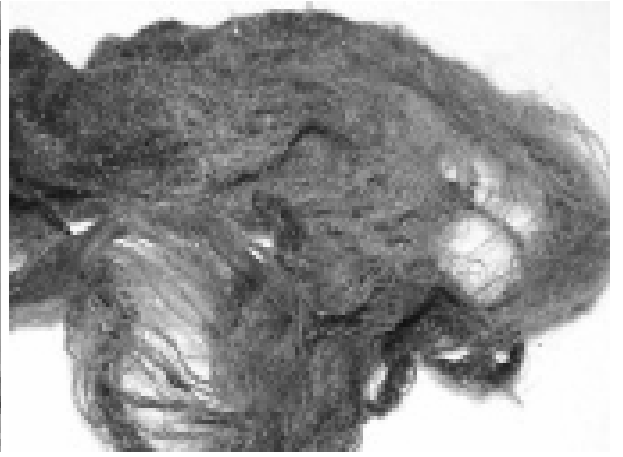

Fig. 2. Spirogyra sp

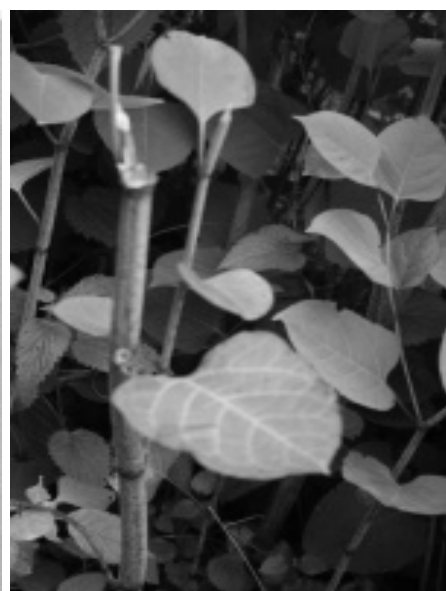

Fig. 4. Reynoutria japonica 
All samples of Reynoutria japonica used were collected from the same non-urban area in foothills of the Lysá hora mountain, in the area of the Moravskoslezské Beskydy. This sampling area does not have any prior history of contamination by heavy metals. Roots, stems and leaves of this plant were air-dried at room temperature. Dried samples were ground and screened using a sieve shaker; uniform particle size fraction 1-2 mm was obtained. Ion exchange resins manufactured for the same purpose generally feature particle sizes between 0.7 and $1.5 \mathrm{~mm}$. Biosorbent granule size usually ranges between 1 to $2 \mathrm{~mm}$. Particles of roots, stems and leaves were twice washed with $0.01 \mathrm{M}$ of $\mathrm{HCl}$ ( $1 \mathrm{~L}$ of acid per $10 \mathrm{~g}$ of biomass), then with extensive volume of de-ionized water in order to remove soil or debris, and finally washed with distilled water. The biomass samples were then oven-dried at $90^{\circ} \mathrm{C}$ for one day.

\subsection{Chemicals}

$\mathrm{Zn}^{2+}$ ions $\left(\mathrm{ZnSO}_{4} .7 \mathrm{H}_{2} \mathrm{O}\right)$ were used in this study. Test solutions containing this single ion were prepared by diluting proper amount of $1 \mathrm{~g} / \mathrm{L}$ stock solution of zinc ion in order to obtain desired concentrations. Chemicals used were of analytical reagent grade and therefore used without further purification.

\subsection{Procedure of experiments}

\subsubsection{Time course}

Time course of $\mathrm{Zn}^{2+}$ uptake by Chlorella vulgaris, Spirogyra sp. and Reynoutria japonica was investigated. The sorbent with the final concentration $0.5 \mathrm{~g} / \mathrm{L}$ of dried biomass of algae and $1 \mathrm{~g} / \mathrm{L}$ of Reynoutria japonica (leaves, stems, roots) was suspended in $200 \mathrm{ml}$ or $500 \mathrm{ml}$ of zinc ion solution. The flasks were placed on a shaker at $120 \mathrm{rpm}$ at a room temperature (around $25^{\circ} \mathrm{C}$ ) for 24 hours for algae and 6 hours for Reynoutria japonica. The $\mathrm{pH}$ value of the solutions tended to drop during the equilibration and during the sorption experiments it was adjusted with $0.1 \mathrm{M}$ solution of $\mathrm{NaOH}$. The temperature and $\mathrm{pH}$ were measured by a microcomputer meter. Samples were taken from the solution at desired intervals and were filtered through membrane filter Millipore $0.45 \mu \mathrm{m}$ or, in the case of $R$. japonica, through filter paper AK-01 blue, dry. All samples were duplicated with the average presented in the results. The heavy metal concentrations in the resulting supernatant were measured by the Atomic Absorption Spectrophotometry (AAS) Unicam 969, wavelength $213.9 \mathrm{~nm}$.

\subsubsection{Effect of $p H$}

The experiment was conducted at concentration $100 \mathrm{mg} / \mathrm{L}$ of zinc ions for Chlorella vulgaris and $10 \mathrm{mg} / \mathrm{L}$ for Spirogyra $s p$. and Reynoutria japonica, $1 \mathrm{~g} / \mathrm{L}$ biosorbent dose in $50 \mathrm{ml}$ and $500 \mathrm{ml}$ zinc solution for six hours with $\mathrm{pH}$ varying from 4.0-6.0. $\mathrm{pH}$ of the solution was adjusted using $0.1 \mathrm{M} \mathrm{NaOH}$. 


\subsubsection{Adsorption isotherm}

In the present experiment we have determinate adsorption isotherms for zinc. Amounts of $2 \mathrm{~g} / \mathrm{L}$ dry acid-pre-treated biomass of algae and $1 \mathrm{~g} / \mathrm{L}$ dry acid-pre-treated plant biomass (all three types: roots, stems and leaves) were suspended in samples of various concentrations $(10-100 \mathrm{mg} / \mathrm{L})$ of $\mathrm{Zn}^{2+}$ solutions. The $\mathrm{pH}$ of solutions before and during equilibration was adjusted with $0.1 \mathrm{M}$ and $0.01 \mathrm{M}$ solutions of $\mathrm{NaOH}$. After 60 minutes of incubation, zinc samples were filtered in order to remove the biomass and metal concentration in supernatant was measured with AAS. Sorption capacity of the substrate $(q)$ expressed in terms of metal amount sorbed on the unitary biosorbent mass $(\mathrm{mg} / \mathrm{g})$. This parameter has been calculated as indicated below (CIMINO et al., 2000).

$$
q=V\left(C_{i}-C_{f}\right) / S
$$

where:

$V$ - the volume of metal-bearing solution contacted with the sorbent some [L],

$C_{i} \quad$ - initial and residual concentrations of metal in the solution $[\mathrm{mg} / \mathrm{L}]$,

$C_{f}-$ residual concentrations of metal in the solution $[\mathrm{mg} / \mathrm{L}]$,

$S$ - the amount of the added biosorbent $[\mathrm{g}]$.

\section{Results and discussion}

\subsection{Time course}

The kinetics experiments of zinc ions removal from solutions showed that biosorption is the equilibrium process, in which the equilibrium is reached after about 10 minutes. The ions are bound with the biomass steadily, and the final concentration of metal ions remained unchanged for 100 hours (CHOJNACKA et al., 2005).

To determine time course of biosorption of Chlorella sp. biomass we have chosen zinc concentration of $100 \mathrm{mg} / \mathrm{L}$, based on our experience with previous experiments with chromium (CHOVANCOVÁ, 2001). As zinc displayed different behaviour and the efficiency of its removal in high concentration was not sufficient, for following experiments with Spirogyra sp. and Reynoutria japonica we decreased concentrations to $10 \mathrm{mg} / \mathrm{l}$. Nevertheless, for both concentrations $(100 \mathrm{mg} / \mathrm{L}$ and $10 \mathrm{mg} / \mathrm{L})$ it can be concluded that at optimal $\mathrm{pH}$ value 6 (Fig. 5 and 6) zinc binding onto algal and plant biomass is rapid (in the first 10 minutes). During the process, concentration of a metal ion gradually decreases and the equilibrium is reached; the concentration remains almost constant after approximately 100 minutes. Adsorption slowed down in later stages because initially a large number of vacant surface sites may be available for adsorption and after some time, the remaining vacant surface sites may be difficult to occupy due to forces between the solute molecules of the solid and bulk phase (BISHNOI et al., 2007). It is, however, necessary to say that in the case of higher concentration $(100 \mathrm{mg} / \mathrm{L})$ the equilibrium status has not been reached and after about 300 minutes zinc started to be separated out back into the solution (Fig. 5). 


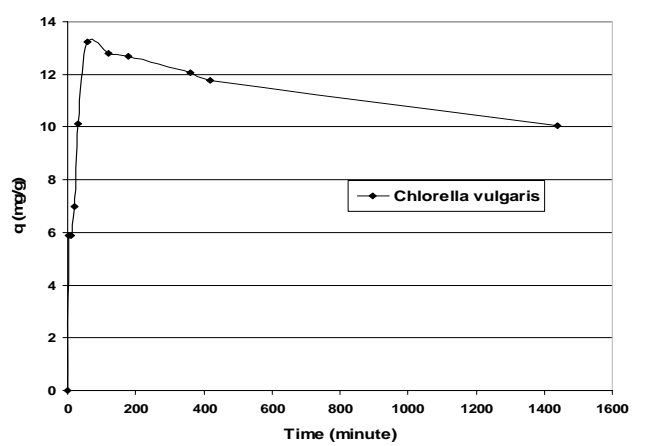

Fig. 5. Time course of metal sorption of divalent zinc by Chlorella vulgaris, $\mathrm{pH}$ 6.0, initial metal concentration $100 \mathrm{mg} / \mathrm{L}$, room temperature $25^{\circ} \mathrm{C}$.

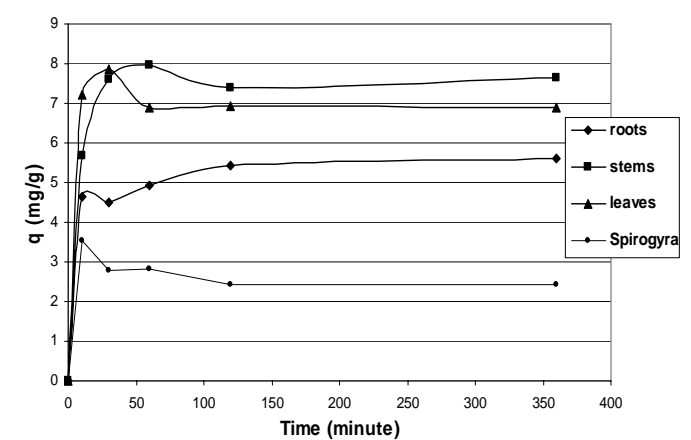

Fig. 6. Time course of metal sorption of divalent zinc by roots, stems and leaves of Reynoutria japonica and Spirogyra sp., $\mathrm{pH} 6.0$, initial metal concentration $10 \mathrm{mg} / \mathrm{L}$, room temperature $25^{\circ} \mathrm{C}$.

\subsection{Effect of $p H$}

$\mathrm{pH}$ is one of the most important environmental factors influencing not only site dissociation, but also the solution chemistry of the heavy metals: hydrolysis, complexation by organic and/or inorganic ligands, redox reactions, and precipitation are strongly influenced by $\mathrm{pH}$ and, on the other side, strongly influence the speciation and the biosorption availability of the heavy metals (ESPOSITO et al., 2002). The effect of $\mathrm{pH}$ on the zinc biosorption capacity of biomass has been shown in Fig. 7. The increase of sorption of zinc ions corresponds to $\mathrm{pH}$ values growing from 4.0 to 6.0, the latter being the optimum $\mathrm{pH}$ for biosorption of zinc ions by all types of biomass. Acid-washed biosorbents can be viewed as natural ion-exchange materials that primary contain weak acid and basic groups (KRATOCHVIL and VOLESKY, 1998). Number of negatively charged active sites (functional groups such as carboxyl, amine, hydroxyl and phosphate groups) at higher $\mathrm{pH}$ increases, facilitating a higher electrical attraction to positively charged metal ions (KLIMMEK et al., 2001; ROMERA et al., 2007). CHOJNACKA et al. (2005) identified in cyanobacteria Spirulina sp. different functional groups at different $\mathrm{pH}$ values. In $\mathrm{pH}$ value range 5.0-9.0, which covers $\mathrm{pH}$ 
value used in our experiments, she identified - with use of potentiometric titration carboxyl and phosphate group to be the main functional groups. Our results of optimum $\mathrm{pH}$ value are in agreement with studies of ROMERA et al. (2001), who studied untreated algae biomass of Spirogyra insignis, and SALEHIZADEH et al. (2003) and NORTON et al. (2004) studying bacteria.

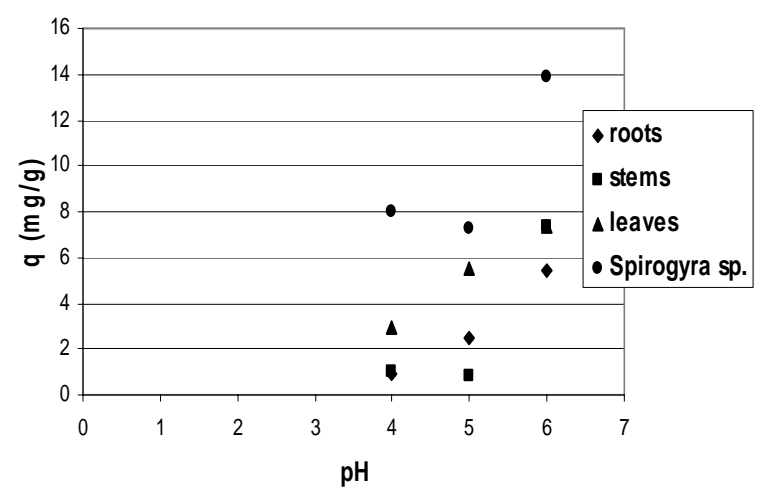

Fig. 7. Effect of $\mathrm{pH}$ on the sorption of $\mathrm{Zn}^{2+}$ by roots, stems and leaves of R. japonica and Spirogyra sp., $\mathrm{pH}$ 4.0-6.0, initial metal concentration $10 \mathrm{mg} / \mathrm{L}$, room temperature $25^{\circ} \mathrm{C}$.

\subsection{Determination of adsorption isotherms}

The Fig. 8 displays metal uptake isotherms for $\mathrm{Zn}^{2+}$ ions plotted against final metal concentration $C_{f}$ in aqueous solutions. When the initial $\mathrm{Zn}^{2+}$ concentration increased from 10 to $50 \mathrm{mg} / \mathrm{L}$, uptake by Chlorella vulgaris increased, and reached $15.9 \mathrm{mg} / \mathrm{g}$.

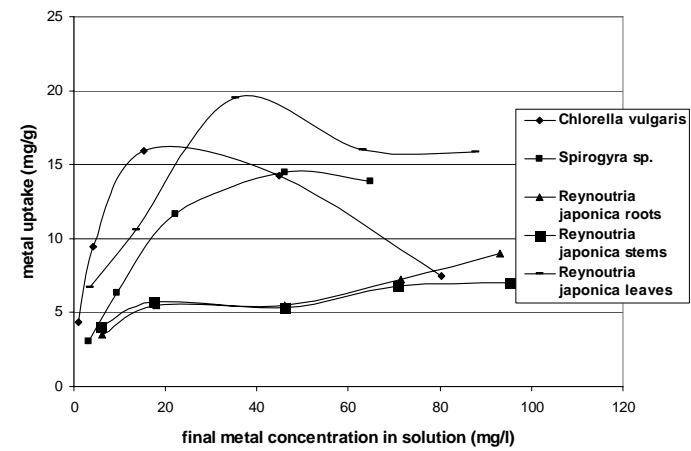

Fig. 8 Sorption isotherms for the sorption of $\mathrm{Zn}^{2+}$ onto Chlorella vulgaris, Spirogyra sp. and roots, stems and leaves of Reynoutria japonica biomass, $\mathrm{pH} 6.0$, room temperature $25.0^{\circ} \mathrm{C}$.

Similar results were obtained with leaves of Reynoutria japonica (uptake 19.5 $\mathrm{mg} / \mathrm{g}$ ), and Spirogyra sp. biomass (uptake $14.5 \mathrm{mg} / \mathrm{g}$ ), both at initial zinc concentration $75 \mathrm{mg} / \mathrm{L}$. It is possible to conclude that in both low and high concentrations, leaves showed the best results. At initial $\mathrm{Zn}^{2+}$ concentration $100 \mathrm{mg} / \mathrm{L}$, decrease of sorption in 
all biomass types was recorded, with the exception of roots and stems of Reynoutria japonica; however these two types of biomass displayed generally the lowest zinc uptake ability among all biomass investigated.

The process of zinc sorption on the biosorbent was described by the Langmuir adsorption model, which is widely used to analyze data for water and wastewater treatment applications. The Langmuir model represents one of the first theoretical descriptions of nonlinear sorption and suggests that uptake occurs on a homogeneous surface by monolayer sorption without interaction between adsorbed molecules. In addition, the model assumes uniform energies of adsorption onto the surface and no transmigration of the adsorbate (SAHMOUNE et al., 2008). The Langmuir equation is given by Eq. (2)

$$
q=q \max b C_{f} / 1+b C_{f}
$$

where:

$q_{\max } \quad-$ maximal metal uptake $[\mathrm{mg} / \mathrm{g}]$,

$b \quad-$ a constant related to the affinity of the binding sites $[\mathrm{L} / \mathrm{mg}]$,

$q \quad$ - experimental metal uptake $[\mathrm{mg} / \mathrm{g}]$,

$C_{f} \quad$ - residual concentrations of metal in the solution $[\mathrm{mg} / \mathrm{L}]$.

$q$ and $b$ can be determined from the linear plot of $C_{f:} / q$ vs. $C_{f}$ (DONMEZ et al., 1999).

The main advantage of this model is the possibility of evaluation of $q_{\max }$ maximum possible quantity of a metal ion adsorbed per gram of adsorbent, and $b-$ parameter related to the affinity of binding sites for a metal ion (MICHALAK et al., 2007). In general, for good biosorbents, high $q_{\max }$ and high $b$ are desirable (DAVIS et al., 2003). The Langmuir constants $\mathrm{R}^{2}$ for the zinc biosorption onto biomass of Chlorella vulgaris, Spirogyra sp. and Reynoutria japonica are showed in Fig. 9 and 10. The results indicate the highest applicability of the Langmuir model for two biosorbents: Spirogyra sp. with the best regression coefficient $\mathrm{R}^{2}=0.9834$, and leaves of Reynoutria japonica $\mathrm{R}^{2}=0.9807$. Based on $q_{\max }$, it can be concluded that Spirogyra sp. $\left(q_{\max }=17.8 \mathrm{mg} / \mathrm{g}\right)$ has slightly higher adsorption capacity for zinc than leaves of Reynoutria japonica $\left(q_{\max }=17.0 \mathrm{mg} / \mathrm{g}\right)$. As for parameter $b$, however, Spirogyra $s p$. has significantly lower $(b=0.06)$ than leaves of Reynoutria japonica $(b=0.26)$. HASHIM and CHU (2004) suggest that a biosorbent with low $q_{\max }$ and high $b$ could outperform a biosorbent with high $q_{\max }$ and low $b$, especially in cases where the metal ion to be removed is present at trace amounts. Therefore, higher $b$ value of leaves of Reynoutria japonica indicates its higher affinity for zinc. Ranking of sorptions of all sorbents studied, based on $q_{\max }$, can be set up as follows: Spirogyra $s p$. $>$ leaves $>$ stems $>$ Chlorella vulgaris $>$ roots of Reynoutria japonica.

Very similar results for Spirogyra sp. were obtained by ROMEA et al. (2007). In his experiments with untreated Spirogyra $s p$. biomass maximum capacity for zinc was found to be $21.6 \mathrm{mg} / \mathrm{g}$, and parameter $b=0.04$. Adsorption capacity for zinc by waste tea leaves biomass (similar type of biomass as leaves of Reynoutria japonica) was found to be $11.8 \mathrm{mg} / \mathrm{g}$ (TEE and KHAN, 1988). 


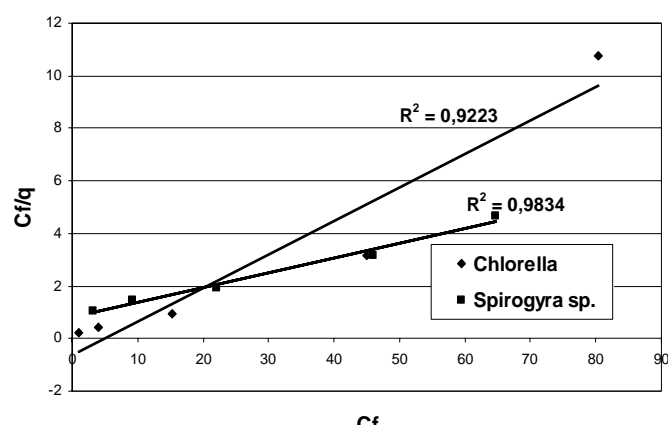

Fig. 9. Sorption isotherms for the sorption of $\mathrm{Zn}^{2+}$ onto Chlorella vulgaris and Spirogyra sp., $\mathrm{pH}$ 6.0, room temperature $25^{\circ} \mathrm{C}$.

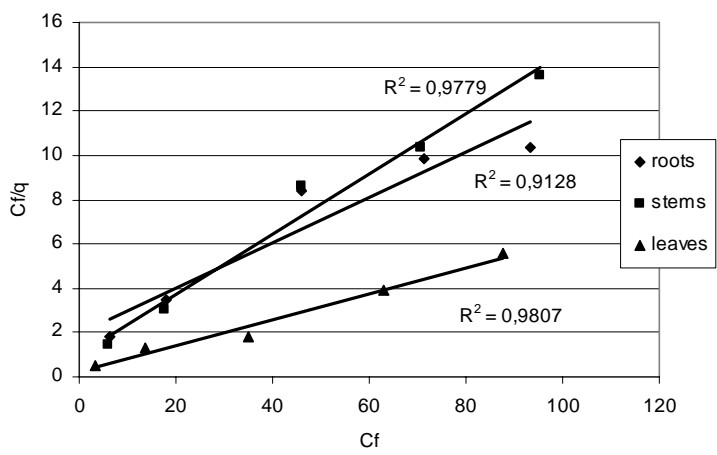

Fig. 10. Sorption isotherms for the sorption of $\mathrm{Zn}^{2+}$ onto roots, stems and leaves of Reynoutria japonica, $\mathrm{pH} 6.0$, room temperature $25^{\circ} \mathrm{C}$.

\section{Conclusions}

This work has demonstrated the possibility of utilization of biomass of algae Chlorella vulgaris and Spirogyra sp., and of a plant Reynoutria japonica for biosorption of zinc ions from aqueous solutions.

The binding capacity of $\mathrm{Zn}^{2+}$ ions to biosorbent has been shown to depend upon $\mathrm{pH}$, with the highest binding at $\mathrm{pH} 6.0$.

The biosorbents have good capacity for zinc adsorption, especially in low metal concentrations.

There were no major differences in biosorption of zinc between cultured Chlorella vulgaris and natural Spirogyra sp. and Reynoutria japonica.

\section{References}

AHLUWALIA, S.S., GOYAL, D.: Microbial and plant derived biomass for removal of heavy metals from wastewater. Bioresour. Technol., 98, 2007, 2243-2257. 
BISHNOI, N.R., KUMAR, R., KUMAR, S., RANI, S.: Biosorption of Cr(III) from aqueous solution using algal biomass Spirogyra spp. J. Hazard. Mater., 135, 2007, $142-147$.

BRADL, H.: Heavy Metals in the Environment. $1^{\text {st }}$ ed. London: Elsevier, 2005, 282 pp.

DAVIS, T.A., VOLESKY, B., MUCCI, A.: A review of the biochemistry of heavy metal biosorption by brown algae. Water Res. 37, 2003, 4311-4330.

DÖNMEZ, G.C., AKSU, Z., OZTURK, A., KUTSAL, T.: A comparative study on heavy metal biosorption characteristics of some algae. Process Biochem., 34, 1999, 885-892.

CIMINO, G., PASSERINI A., TOSCANO, G.: Removal of toxic cations and Cr(VI) form aqueous solution by Hazelnut shell. Wat. Res., 34, 2000, 2955-2962.

ESPOSITO, A., PAGNANELLI, F., VEGLIO, F.: pH-related equilibrium models for biosorption in single metal systems. Chem. Eng. Sci., 57, 2002, 307-313.

GUPTA, V.K., RASTOGI, A.: Biosorption of lead from aqueous solution by green algae Spirogyra sp.: Kinetics and equilibrium studies. J. Hazard. Mater., 152, 2008, 407-414.

GUPTA, V.K., RASTOGI, A., SAINI, V.K., JAIN, N.: Biosorption of copper(II) from aqueous solutions by Spirogyra species. J. Colloid Interface Sci., 296, 2006, 59-63.

GUPTA, V.K., SHARMA, S.: Removal of zinc from aqueous solutions using bagasse fly ash - a low cost adsorbent. Ind. Eng. Chem. Res., 42, 2003, 6619-6624.

HAASE, E.: Pflanzen reiningen Schwermetall-Böden. Umwelt (Dusseldorf), 7-8, $1988,342-344$

HASHIM, M.A., CHU, K.H.: Biosorption of cadmium by brown, green and red seaweeds, Chem. Eng. J. 97, 2004, 249-255.

CHOJNACKA, K., CHOJNACKI, A., GÓRECKA. H.: Biosorption of $\mathrm{Cr}^{3+}, \mathrm{Cd}^{2+}$ and $\mathrm{Cu}^{2+}$ ions by blue-green algae Spirulina sp.: kinetics, equilibrium and the mechanism of the process. Chemosphere, 59, 2005, 75-84.

CHOJNACKA, K.: Using biosorption to enrich the biomass of Chlorella vulgaris with microelements to be used as mineral feed supplement. World J. Microbiol. Biotechnol. 23, 2007, 1139-1147.

CHOVANCOVÁ,I.: Uptake of trivalent chromium by biosorbent of algae of Chlorella vulgaris, New Trends in Mineral Processing IV, Ostrava 28-30.6. 2001, 493-501.

KADUKOVÁ, J., VIRČÍKOVÁ, E.: Comparison of differences between copper bioaccumulation and biosorption. Environ. Int., 31, 2005, 227- 232.

KLIMMEK, S., STAN, H.-J., WILKE, A., BUNKE, G. BUCHHOLZ. R.: Comparative analysis of the biosorption of cadmium, lead, nickel, and zinc by algae. Environ. Sci. Technol., 35, 2001, 4283-4288.

MICHALAK, I., ZIELINSKA, A., CHOJNACKA, K., MATULA, J.: Biosorption Cr (III) by Microalgae and Macroalgae: Equilibrium of the Process. Am. J. Agri. Biol. Sci., 2, 2007, 284-290.

ROMERA, E., GONZALEZ, F., BALlESTER, A., BLAZQUEZ, M.L., MUNOZ, J.A.: Biosorption with algae: statistical review. Crit. Rev. Biotechnol., 26, 2006, 223-35.

SALEHIZADEH, H., SHOJAOSADATI, S.A.: Removal of metal ions from aqueous solution by polysaccharide produced from Bacillus firmus. Water Res., 17, 2003, 4231-4235. 
TEE, T.W., KHAN, A.R.M.: Removal of lead, cadmium and zinc by waste tea leaves. Environ. Technol. Lett., 9, 1988, 1223-32.

VÁŇA J., ROTH, J.: Zabezpečení fytopaliva v oblasti elektrárny Tušimice. Dílčí zpráva. Envicho s.r.o., Chomutov, 1994.

VOLESKY, B.: Detoxification of metal-bearing effluents: biosorption for the next century. Hydrometallurgy, 59, 2001, 203-216.

WANG, J.,CHEN, C: Biosorbents for heavy metals removal and their future. Biotechnol. Adv., 27, 2009, 195-226.

WILliAMS, C.J., ADERHOL, D., EDYVEAN, R.G.J.: Comparison between biosorbents for the removal of metal ions from aqueous solutions, Water Res., 32, 1998, 216-224. 